\title{
Mapping surface soil moisture over the Gourma mesoscale site (Mali) by using ENVISAT ASAR data
}

\author{
F. Baup ${ }^{1}$, E. Mougin ${ }^{2}$, P. de Rosnay ${ }^{3}$, P. Hiernaux ${ }^{2}$, F. Frappart ${ }^{2}$, P. L. Frison ${ }^{4}$, M. Zribi ${ }^{1}$, and J. Viarre ${ }^{2}$ \\ ${ }^{1}$ CESBIO (Centre d'Etudes Spatiales de la Biosphère, UMR 5126, UPS-CNRS-CNES-IRD), 18 avenue Edouard \\ Belin, 31401 Toulouse cedex 9, France \\ ${ }^{2}$ GET (Géosciences Environnement Toulouse, UMR 5563 CNRS-UPS-IRD) Observatoire Midi-Pyrénées \\ 14 avenue Edouard Belin, 31400 Toulouse, France \\ ${ }^{3}$ ECMWF (European Centre for Medium-Range Forecasts), Reading, Berkshire, UK \\ ${ }^{4}$ Laboratoire des Géomatériaux, Université Marne La Vallée, Institut Francilien des Sciences Appliquées, \\ 5 bd Descartes, 77454 Marne la Vallée Cedex 2, France
}

Received: 23 July 2010 - Published in Hydrol. Earth Syst. Sci. Discuss.: 28 September 2010

Revised: 20 January 2011 - Accepted: 31 January 2011 - Published: 18 February 2011

\begin{abstract}
The potentialities of ENVISAT ASAR (Advanced Synthetic Aperture Radar) multi-angle data for mapping surface soil moisture (SSM) in Sahelian rangelands are investigated at medium scale $\left(30000 \mathrm{~km}^{2}\right)$. The Wide Swath data are selected to take advantage of their high temporal repetitivity (about 8 days at the considered scale) associated to a moderate spatial resolution $(150 \mathrm{~m})$. In the continuity of previous studies conducted at a local scale in the same region, SSM maps are here processed over the whole AMMA Gourma mesoscale site at $1 \mathrm{~km}$ resolution scale. Overall, the generated maps are found to be in good agreement with field data, EPSAT-SG (Estimation des Pluies par SATellite - Second Generation) rainfall estimates and ERS (European Remote Sensing) Wind Scatterometer (WSC) SSM products. The present study shows that the spatial pattern of SSM can be realistically estimated at a kilometric scale. The resulting SSM maps are expected to provide valuable information for initialisation of land surface models and the estimation of the spatial distribution of radiative fluxes. Particularly, SSM maps could help to desaggregate low-resolution products such as those derived from WSC data.
\end{abstract}

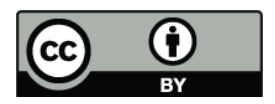

Correspondence to: F. Baup

(frederic.baup@cesbio.cnes.fr)

\section{Introduction}

Soil moisture monitoring over the Sahel is a major issue of the agenda of the AMMA (African Monsoon Multidisciplinary Analysis) project which aims at a better understanding of the West African Monsoon and its physical, chemical and biological environments (GEWEX-news, 2006). Monitoring the spatio-temporal variability of soil moisture is also needed to better understand soil-vegetation-atmosphere interactions and to address the role of soil moisture on West African monsoon dynamics (e.g. Monteny et al., 1997; Clark et al., 2004; Taylor and Ellis, 2006). Moreover, surface soil moisture (SSM) is a key parameter for surface processes which govern the incident solar energy partitioning between surface heat and water fluxes.

For over 20 years, microwave remote sensing has been demonstrating capabilities to estimate SSM under a large variety of topographic and vegetation cover conditions. Several large-scale field experiments that included aircraft microwave radiometric measures were conducted within the framework of HAPEX-Sahel, FIFE, Monsoon'90, SMEX and NAFE'05 (Schmugge et al., 1992; Jackson et al., 2005; Panciera et al., 2008; Mladenova et al., 2010). So far, passive and active sensors have been used to map SSM over semi arid areas by using C- and L- band frequencies (e.g. Chanzy et al., 1997; Frison et al, 1998; Wagner and Scipal, 2000; Jarlan et al., 2002; Njoku et al., 2003; Zribi et al., 2008). These independent multi-frequency and multiresolution sensors offer complementary information due to

Published by Copernicus Publications on behalf of the European Geosciences Union. 
their different interactions with the surface components (soil and vegetation). L-band data are less influenced by the vegetation contribution due to a higher wave penetration into the vegetation and thus are more correlated with SSM. Although C-band data are more influenced by the vegetation canopy, they are also strongly linked to SSM in semi-arid regions where the vegetation cover is low (Ulaby et al., 1982; Wagner and Scipal, 2000; Zine et al., 2005; Zribi et al., 2008, Wagner et al., 2008).

The last generation of spaceborne radars, such as the Advanced Synthetic Aperture Radar (ASAR) onboard ENVISAT or RADARSAT, provides images combining a high spatial resolution $(\leq 150 \mathrm{~m})$ and a large spatial cover (up to $500 \mathrm{~km}$ ) at C-band frequency. Particularly, the ASAR Wide Swath mode provides images with a high temporal sampling (3-4 days at local scale and 8 days at meso-scale) associated to a moderate spatial resolution $(150 \mathrm{~m})$. Others ASAR modes such as Alternating polarisation or Image modes could also be used for improving SSM estimates. However, for the time being, their use is constrained by their low spatial coverage that is lower than $100 \mathrm{~km}$ (ENVISAT ASAR product Handbook, 2007). Besides, the Global Monitoring mode offers a significantly better temporal resolution (a few days) with a moderate spatial resolution $(1 \mathrm{~km})$. However, its poor radiometric performance in terms of radiometric accuracy and stability limits its use to regional to global analysis (e.g. Baup et al., 2007b; Pathe et al., 2009, Mladenova et al., 2010).

SSM estimation can take advantage of the multi-angular capabilities of SAR antenna providing complementary information from the surface (soil and vegetation). Indeed, the influence of the green vegetation can be either neglected or simply taken into account at low incidence angles and for low vegetation density (Leaf Area Index $-\mathrm{LAI}-<2 \mathrm{~m}^{2} \mathrm{~m}^{-2}$ ) as proposed in Tansey et al., 1999 and Moran et al., 2000. At higher incidence angles, the vegetation effects on the radar signal can be corrected using the angular properties of the backscattering coefficient (Wagner et al., 2000; Baup et al., 2007a). Finally, the determination of SSM was found to be possible from ASAR data, for values higher than $4 \%$ $\left(\mathrm{m}^{3} / \mathrm{m}^{3}\right)$. Below this threshold, the radar signal instability ( $\pm 0.6 \mathrm{~dB}$ for ENVISAT/ASAR) combined with unknown surface temporal changes prevent from an accurate SSM estimation (Moran et al., 2000; Mattia et al., 2006; Baup et al., 2007a; Zribi et al., 2008).

In the framework of the AMMA project, meso-scale sites have been instrumented in Mali, Niger and Benin, providing ground data along the latitudinal gradient between Sahelian and Sudanian bioclimatic regions (Lebel et al., 2009; Cappelaere et al., 2009; Mougin et al., 2009a; de Rosnay et al., 2009).

The aims of the present study are (1) to generalize a recently proposed method for SSM monitoring over sandy soils of the Sahel (Baup et al., 2007a) to soil erosion (rocky) surfaces. Both surfaces account for more than $90 \%$ of the considered region. Here, we use data collected at a second sandy site and a rocky site located in the same region in Mali, (2) to generate time series of SSM maps at mesoscale $\left(1^{\circ} \times 3^{\circ}\right)$ with the help of a soil map, (3) to evaluate the validity of the generated SSM maps at meso-scale with relevant and available SSM (Zribi et al., 2008) and rainfall products (Bergès and Chopin, 2004).

To this end, we use HH-polarized ENVISAT/ASAR Wide Swath data which combine high spatial coverage, moderate spatial resolution and high temporal sampling. The paper is organised as follows: the data used (ground and satellite) and the overall methodology are presented in Sect. 2. Then, the performance of the algorithm is evaluated using EPSATSG (Estimation des Pluies par SATellite - Second Generation) rainfall products, European Remote Sensing (ERS) wind scatterometer SSM products and local raingauges data (Sect. 3). Conclusions on the relevance of ASAR SSM maps and perspectives are given in Sect. 4.

\section{Data and methods}

\subsection{The study site}

The Gourma meso-scale site $\left(1^{\circ} \mathrm{W}-2^{\circ} \mathrm{W}, 14.5^{\circ} \mathrm{N}-17.5^{\circ} \mathrm{N}\right)$ is entirely located within the Sahel bioclimatic zone (Mougin et al., 2009a). This region, mainly pastoral, is bracketed by the 150 and $500 \mathrm{~mm}$ isohyets. The rain distribution is strictly mono-modal with rainfall starting in June and ending in September with a maximum in August (Frappart et al., 2009). This short rainy season is followed by a long dry season during which there is no green vegetation except for rare perennial herbaceous and the foliage of some of scattered trees and shrubs (Hiernaux et al., 2009). Bare soils are thus very much exposed during most of the dry season with contrasted colors, textures and roughness (Fig. 1a-b).

During the wet season, rangeland vegetation is composed of a low herbaceous layer dominated by annuals and a sparse woody plant population (mean $<5 \%$ cover). Annual herbs growth is governed by soil moisture regime itself driven by the pattern and magnitude of the rain events, and by run-off function of rain intensity, topography and soil texture (Casenave and Valentin, 1989). Annual herbs germinate with the first marked rains, in June or July, and unless the plants wilt before maturity owing to a lack of rainfall, the senescence coincides approximately with the end of the rainy season, several days after the drying up of soils. Evapotranspiration over the grassland commonly ranges $1-3 \mathrm{~mm} \mathrm{day}^{-1}$ and can reaches 3-4 mm day ${ }^{-1}$ (Timouk et al., 2009).

\subsection{Ground data}

This section presents the available ground data collected in 2005 for the processing and the evaluation of the SSM maps. Three different datasets are described: Surface Soil Moisture, rainfall and soil types. 

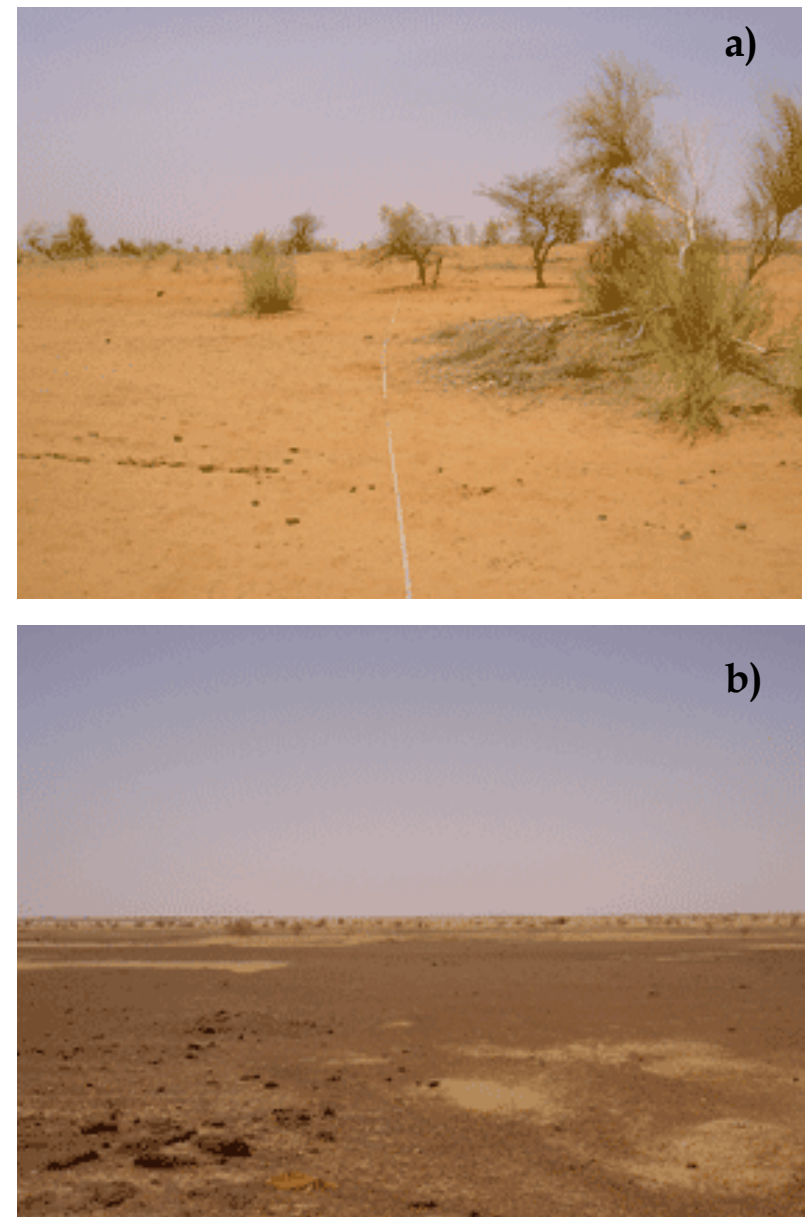

Fig. 1. Views of the Agoufou (a), Eguerit (b) sites during the dry season in April.

\subsubsection{SSM measurements}

The objectives of the soil moisture stations network are to collect information about the spatio-temporal variation of soil moisture over the meso-scale window at different depths (de Rosnay et al., 2009). From April to December 2005, soil moisture was automatically recorded at 15 or 30 minutes time step at two sandy local sites, namely Agoufou $\left(15.3^{\circ} \mathrm{N}\right.$, $\left.1.5^{\circ} \mathrm{W}\right)$, and Ebang Mallam $\left(15.4^{\circ} \mathrm{N}, 1.3^{\circ} \mathrm{W}\right)$ and one erosion surface (rocky) site: Eguerit $\left(15.5^{\circ} \mathrm{N}, 1.4^{\circ} \mathrm{W}\right)$ (Fig. 2). Only measurements recorded at $5 \mathrm{~cm}$ depth are considered in accordance with the microwave soil penetration depth (Ulaby et al., 1981).

In all sites, soil moisture is measured by reflectometers (Campbell Scientific CS616). Sensors are calibrated by using in situ gravimetric measurements and estimation of soil bulk density. In this study, SSM is expressed in volumetric water content $\left(\mathrm{m}^{3} / \mathrm{m}^{3}\right)$ in accordance with the calibration method presented in de Rosnay et al., 2009. Figure 3a and b illustrate the temporal variation of SSM for the Agoufou sandy - and Eguerit rocky- sites.

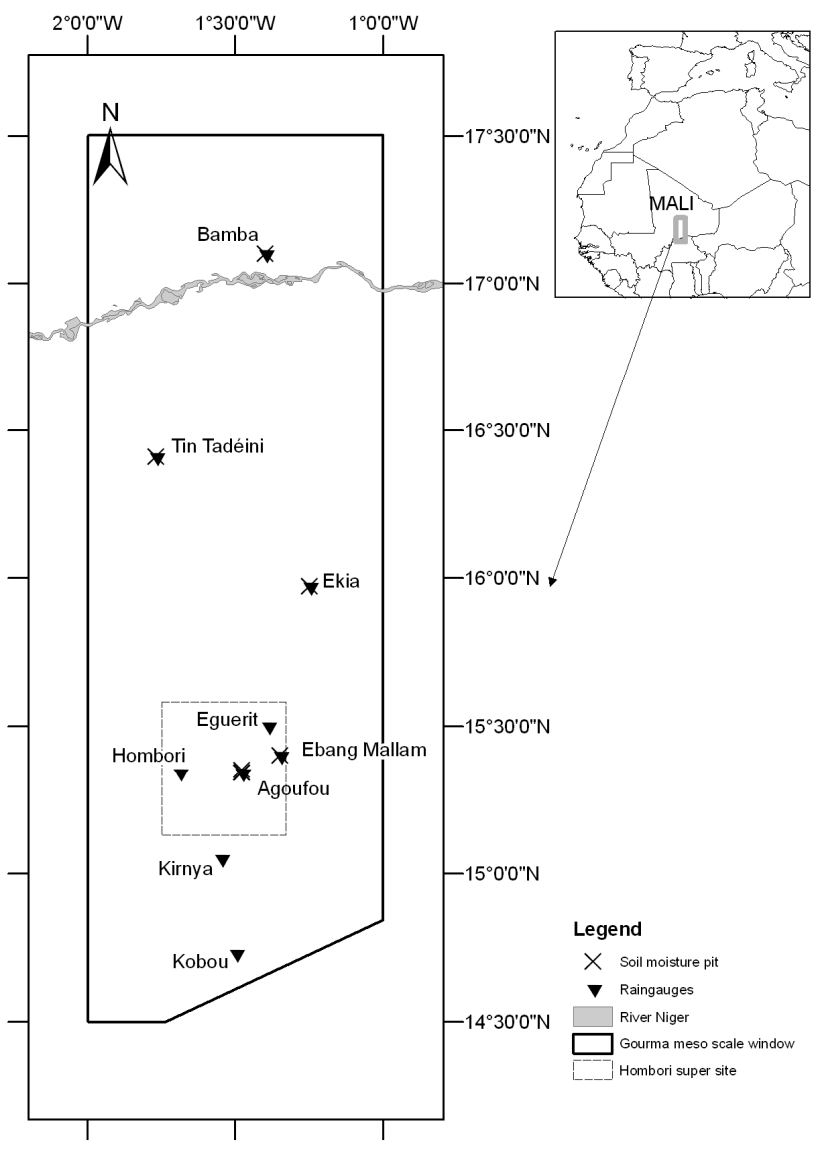

Fig. 2. The AMMA mesoscale site in Gourma (Mali) $\left(1^{\circ} \mathrm{W}-\right.$ $\left.2^{\circ} \mathrm{W} / 14.5^{\circ} \mathrm{N}-17.5^{\circ} \mathrm{N}\right)$ showing the location of the soil moisture stations and automatic raingauges in 2005 .

During the dry season, SSM is close to $0.05 \%$ and reaches values as high as $18 \%$ at Agoufou during the wet season. At the Eguerit site, SSM values range between $3.5 \%$ and $15 \%$. Local SSM measured by automatic stations typically range between 0.05 and $24 \%$ over the whole meso-scale site (de Rosnay et al., 2009).

\subsubsection{Rainfall measurements}

Rainfalls are recorded by a network of 8 automatic rain gauges distributed along the latitudinal climatic gradient (Fig. 2). Rainfall data are summed over different time step depending of the site (Table 1). In the following, only the Agoufou (Ag) and the Tin Tadeini (TT) station data are detailed but all the stations are nevertheless used in the analyses. 
Table 1. Raingauges acquisitions time step.

\begin{tabular}{lllllllll}
\hline $\begin{array}{l}\text { Raingauge } \\
\text { location }\end{array}$ & $\begin{array}{l}\text { Tin } \\
\text { Tadeini }\end{array}$ & Ekia & Eguerit & $\begin{array}{l}\text { Bangui } \\
\text { Mallam }\end{array}$ & Agoufou & Hombori & Kyrnia & Kobou \\
\hline $\begin{array}{l}\text { Acquisition } \\
\text { time step }\end{array}$ & $\begin{array}{l}\text { real } \\
\text { time }\end{array}$ & $\begin{array}{l}\text { real } \\
\text { time }\end{array}$ & $15 \mathrm{~min}$ & $\begin{array}{l}\text { real } \\
\text { time }\end{array}$ & $15 \mathrm{~min}$ & Daily & $\begin{array}{l}\text { real } \\
\text { time }\end{array}$ & $\begin{array}{l}\text { real } \\
\text { time }\end{array}$ \\
\hline
\end{tabular}
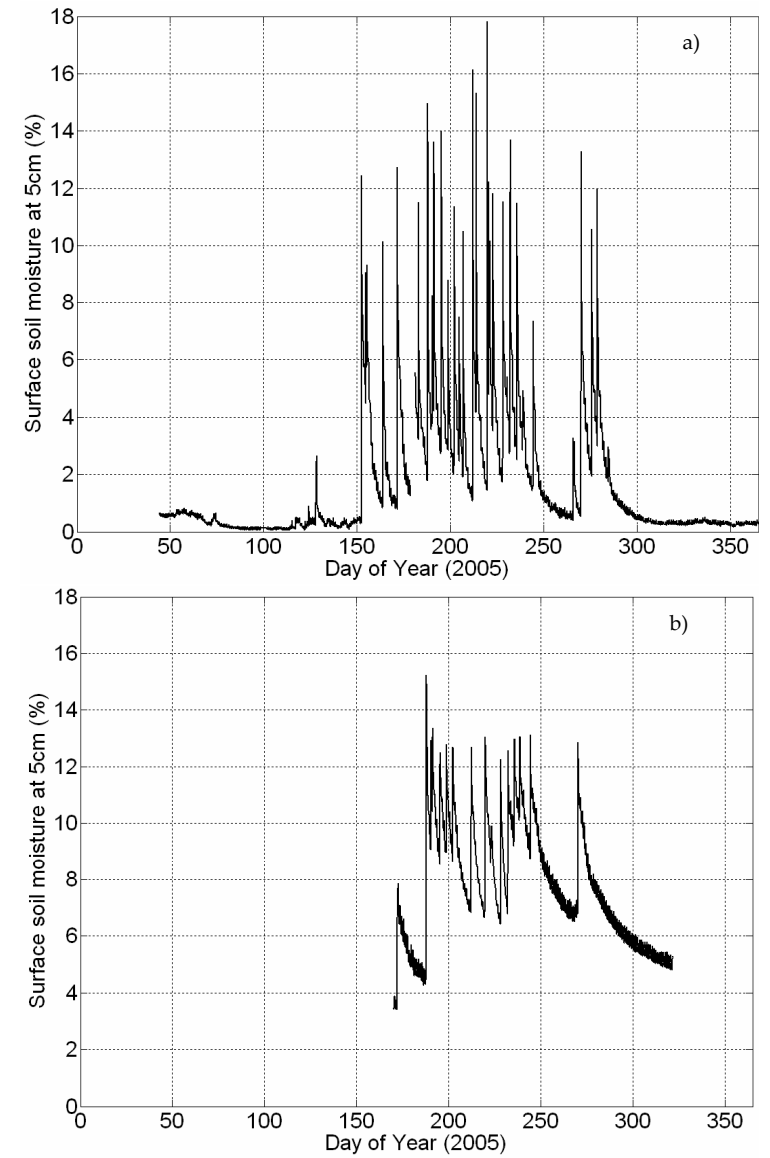

Fig. 3. Seasonal variation of surface soil moisture (SSM) at $5 \mathrm{~cm}$ depth at the Agoufou sandy (a) and Eguerit rocky (b) sites in 2005.

\subsubsection{Soil map}

Over the Gourma region, nine soil types are mapped by visual interpretation of a mosaic of Landsat TM images at a resolution of $30 \mathrm{~m}$ and systematic field observations (Mougin et al., 2009a). Soil surface types are defined according to topography, terrain morphology, top soil texture and soil surface features. Soil types (initially divided in 9 classes) are grouped in 4 dominant classes (clay, mixed, sandy and rocky) and presented in Figure 4 at meso-scale and supersite scales. For best clarity, only main classes are presented for the meso-scale site. Each class is represented by its cover percentage varying from 0 to $100 \%$. The sandy and rocky soil classes contribute more than $90 \%$ of the study site.

\subsection{Satellite data}

\section{ENVISAT ASAR}

The ENVISAT satellite was launched by ESA (European Space Agency) on 1 March 2002. The ASAR instrument is a multi-mode sensor which operates at C-band $(5.3 \mathrm{GHz})$ at several polarizations ( $\mathrm{HH}, \mathrm{VV}, \mathrm{HV}$ and $\mathrm{VH})$, incidence angles, and spatial/radiometric resolutions depending on the functioning mode (Desnos et al., 1999). At the C-band frequency, atmospheric perturbations, except originating from strong precipitation systems, can be considered negligible (Ulaby et al., 1981). ASAR data are provided by the ScanSAR Wide Swath (WS) mode at HH polarization, at a spatial resolution of $150 \mathrm{~m}$ and incidence angles range between $16^{\circ}$ and $43^{\circ}$ (ENVISAT handbook, 2007). The confidence interval is estimated at $\pm 0.6 \mathrm{~dB}$ at $1 \sigma$ (where $\sigma$ denotes the standard deviation), over the $1 \times 1 \mathrm{~km}^{2}$ sites (Baup et al., 2007b).

From July to December 2005, 23 images were acquired at various incidence angles over the AMMA meso-scale site. Only 7 images were analyzed: 5 for the wet season and 2 for the dry season (Table 2). The 16 other images have been acquired during the dry season and are characterized by very low and almost constant SSM. The 7 selected images are calibrated with the B.E.S.T. (Basic ENVISAT SAR Toolbox) software algorithm described in Laur et al. (1998). Then, their geolocation is improved by using ground control points taken from a Landsat TM image at a spatial resolution of $30 \mathrm{~m}$. Mean offsets of 1 pixel $(75 \mathrm{~m})$ in latitude and 7 pixels $(525 \mathrm{~m})$ in longitude have been observed and corrected for.

\section{ERS Scatterometer data}

The ERS WSC was initially designed to measure wind speed and direction at the sea surface. The instrument consists of three antennas, which transmit radar beams that are pointed $45^{\circ}$ forward, $45^{\circ}$ sideways, and $45^{\circ}$ backward with respect to the satellite nadir. The incidence angle $\theta$ varies over the instrument swath from $18^{\circ}$ to $47^{\circ}$ for the midbeam antenna and from $25^{\circ}$ to $59^{\circ}$ for the fore-beam and aft-beam antennas (Mougin et al., 1995; Frison and Mougin, 1996). The sensor 


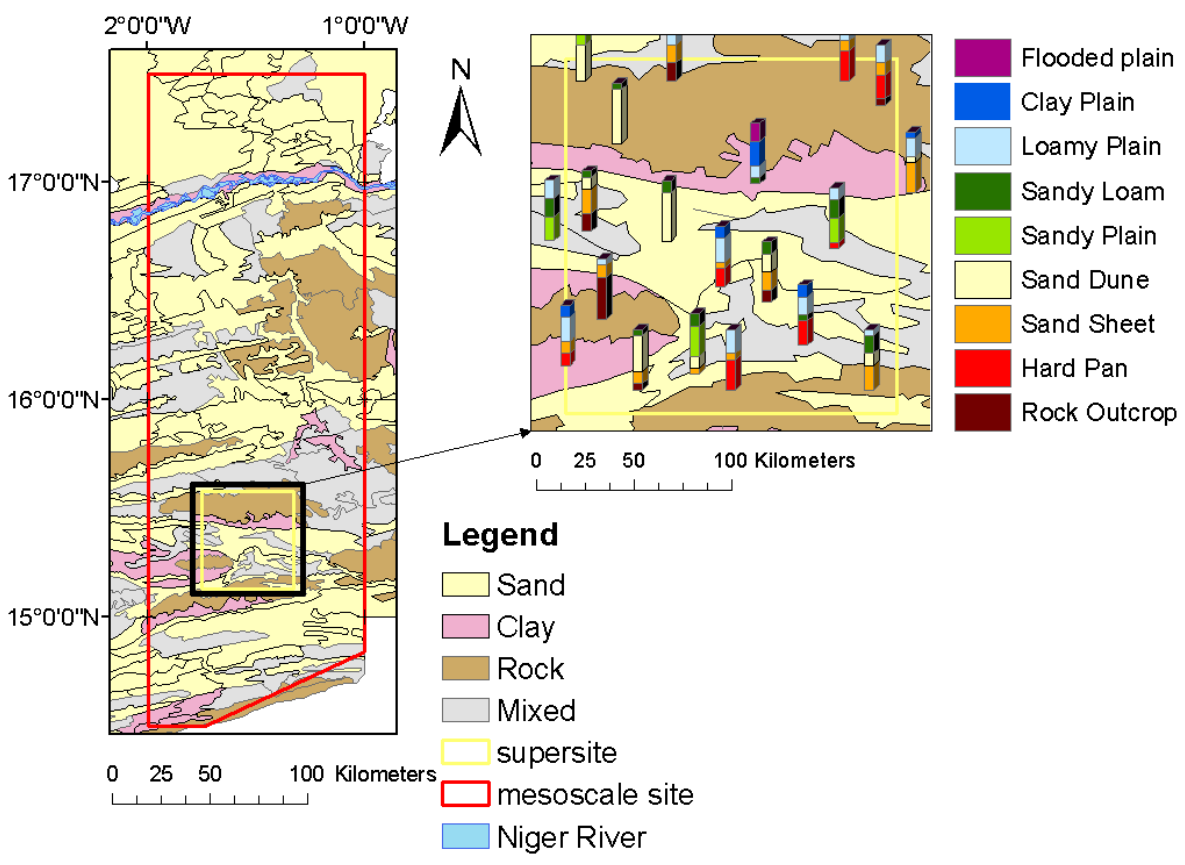

Fig. 4. Soil types map of the AMMA meso-scale site in Mali. The 9 soil types (stacked bars) are grouped into 4 dominant soil texture classes (polygons)

Table 2. Dates, time and orbit passes (Descending (D) or Ascending (A)) of radar image used in this study.

\begin{tabular}{lrrc|r}
\hline \multirow{2}{*}{ Season } & \multicolumn{2}{c|}{ ASAR } & WSC \\
& Date & Time & Orbit & Date \\
\hline wet & $16 / 07 / 2005$ & $10: 03: 41$ & D & $04 / 07 / 2005$ \\
wet & $4 / 08 / 2005$ & $10: 06: 28$ & D & $4 / 08 / 2005$ \\
wet & $20 / 08 / 2005$ & $10: 03: 36$ & D & $20 / 08 / 2005$ \\
wet & $3 / 09 / 2005$ & $22: 06: 13$ & A & $3 / 09 / 2005$ \\
wet & $8 / 09 / 2005$ & $10: 06: 25$ & D & $8 / 09 / 2005$ \\
dry & $19 / 12 / 2005$ & $10: 00: 29$ & D & - \\
dry & $20 / 12 / 2005$ & $22: 11: 58$ & A & - \\
\hline
\end{tabular}

operates at $5.3 \mathrm{GHz}$ and VV polarization, like the ERS/SAR instrument. Its spatial resolution is around $50 \mathrm{~km}$, and measurements are repeated every three to four days. The data are processed using a grid with elementary $0.25^{\circ}$ square cells. The methodology presented in Zribi et al. (2008) enables SSM products to be obtained at regional scale over West Africa. Angular normalisation is applied for each cell and local empirical surface soil moisture inversion functions are applied at larger scale. Vegetation and soil roughness variations are interpreted as a "dry signal" as presented in Zribi et al. (2008). The observed variations of the backscattering signal above the dry signal are attributed to SSM changes.

\section{EPSAT-SG data}

EPSAT-SG (Estimation des Pluies par SATellite - Second Generation) precipitation products are generated at LMD (Laboratoire de Météorologie Dynamique) within the framework of AMMA. Satellite and raingauge data are used to produce high resolution rainfall estimations. The EPSATSG algorithm is composed of two parts: the computation of rainfall probability and the actual rainfall estimation (Bergès et al., 2005). Rainfall probabilities are computed using a feed forward neural network from MSG (Meteosat Second Generation), multi-spectral images and TRMM PR (Tropical Rainfall Measuring Mission Precipitation Radar) data. For every 15 minutes MSG image, a rainfall probability map is produced (Bergès and Chopin, 2004). Then, potential rainfall intensity maps are computed merging GPCP-1dd (Global Precipitation Climatology Project at one degree of space resolution) information with the rainfall probability map. The estimated rainfall intensity is the product of the rainfall probability and the potential intensity (Chopin et al., 2005).

The AMMA project provides rain rates within gridded surface over West Africa (from $25^{\circ} \mathrm{W}$ to $25^{\circ} \mathrm{E}$ and from $20^{\circ} \mathrm{N}$ to $5^{\circ} \mathrm{S}$ ) estimated with the EPSAT-SG algorithm at a spatial resolution of $0.1^{\circ}$ and a temporal resolution of $30 \mathrm{~min}$ from June to September (mid-October in 2005) over the 20042006 period (http://bddamma.ipsl.polytechnique.fr/). An evaluation of EPSAT-SG 2005-products over the meso-scale site with ground gauges shows that the EPSAT pentadal rainfall estimates are sufficiently accurate for comparing rainfall 


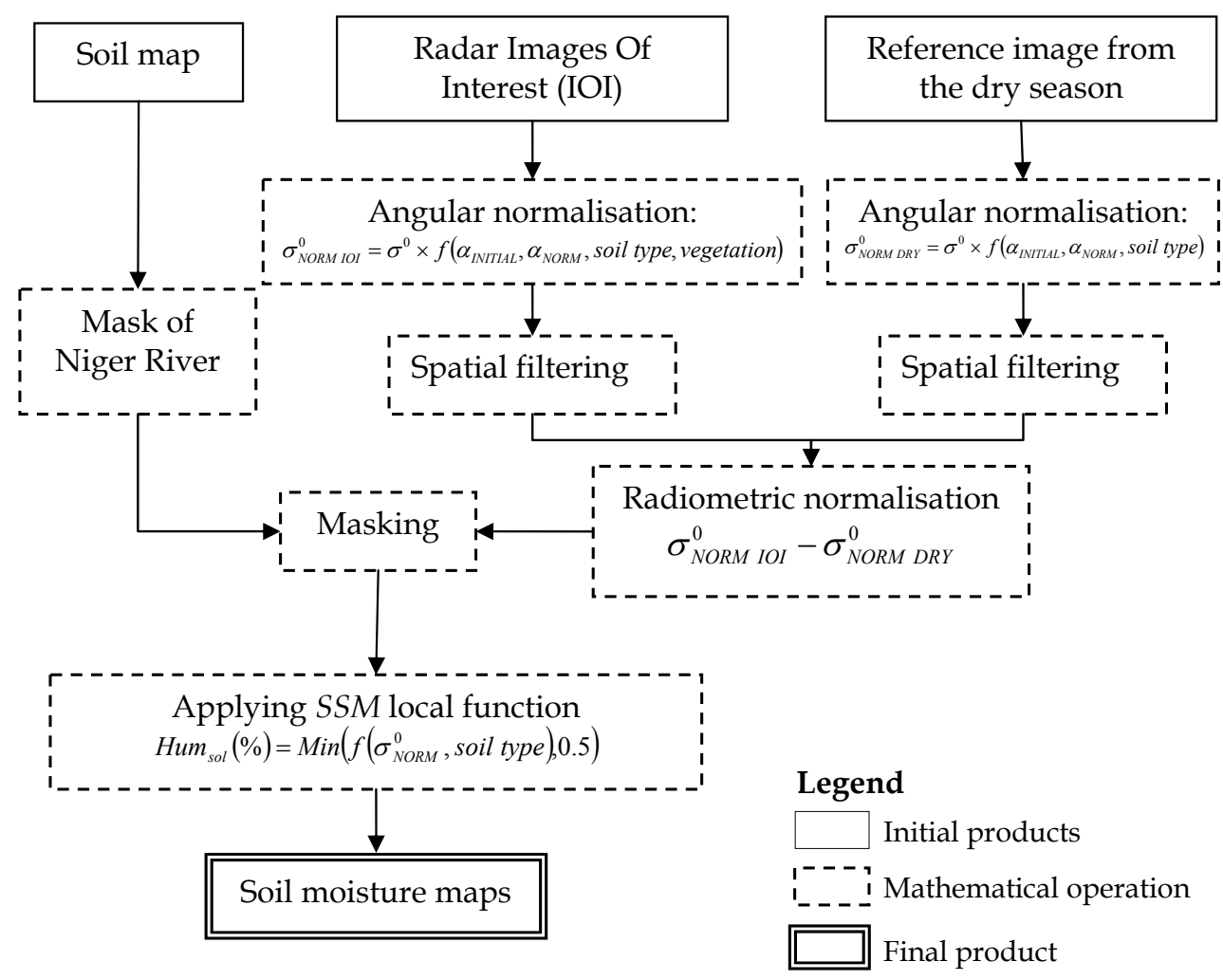

Fig. 5. Chart of the surface soil moisture (SSM) mapping algorithm. $\alpha_{\text {INITIAL }}$ and $\alpha_{\text {NORM }}$ respectively represent the initial acquisition angle and the angle of normalization.

and soil moisture patterns. A relatively good agreement is obtained for rainfall amounts lower than $20 \mathrm{~mm}$ whereas higher rainfalls are underestimated by EPSAT-SG.

For the need of the study, the rain rates are summed either over 1 or over 5 days.

\subsection{Methodology of surface soil moisture mapping}

The SSM maps are produced from satellite and ground data in a several process steps (Fig. 5).

1. The proposed methodology consists of an angularnormalization of ASAR images depending on the acquisition angle, soil type and vegetation. Despite a low vegetation cover in this semi-arid region, a vegetation correction is applied to take into account (1) the strong spatial heterogeneities of the vegetation cover, (2) the inter-annual variations of the vegetation cover. Particularly, this correction is relevant for wet years for which the vegetation cover is well developed. The normalization method consists in characterizing the angular variation function of the backscattering coefficient for different soil types (Baup et al., 2007b). Over sandy soils, two normalization functions are used depending on the amount of vegetation. For the dry season (from October to May) when the green herbaceous layer is absent, the normalization function is derived from all data acquired at various incidence angles to establish the angular regression function which is approximated by a second order polynomial fit. For the wet season, a simple normalization function is built by considering all of the ASAR data recorded at the date of maximum green vegetation cover (Baup et al., 2007a). Vegetation effects are taken into account after the start of the herbaceous vegetation growth. This period is detected by using Normalized Difference Vegetation Index (NDVI) images acquired by the Moderate Resolution Imaging Spectroradiometer (MODIS). Here, a NDVI threshold of 0.14 is retained corresponding to the offset observed on the MODIS data acquired during the dry season over the sandy surfaces of the Malian meso-scale site (Mougin et al., 2009b). Over rocky erosion and hard pan surfaces, vegetation effects are neglected since the vegetation cover remains generally very low, even during the wet season (Hiernaux et al., 2009). In accordance with previous studies (Baup et al., 2007a, b), the angular variation function is used to normalise the radar data at $23^{\circ}$ of incidence angle.

2. Normalized images are filtered to reduce speckle effects using the spatial GAMMA filter of the ENVI 4.2 software (ENVI, 1998). The image resolution is thus 
Table 3. Statistical parameters of the soil roughness at Agoufou (sandy soil) during the dry and the wet seasons: hrms is the root mean square value of the roughness height, lc is the corellation length, Std is the standard deviation.

\begin{tabular}{lcccc}
\hline & $\begin{array}{c}\text { hrms } \\
(\mathrm{cm})\end{array}$ & $\begin{array}{c}\text { Std (hrms) } \\
(\mathrm{cm})\end{array}$ & $\begin{array}{c}\text { Lc } \\
(\mathrm{cm})\end{array}$ & Std(lc) \\
\hline Dry season & 0.7 & 0.3 & 12.6 & 6.9 \\
Wet season & 0.5 & 0.3 & 13.5 & 7.0 \\
\hline
\end{tabular}

degraded from $150 \mathrm{~m}$ to $1 \mathrm{~km}$ as a result of the filter application.

3. The radiometric correction step consists of processing the difference between one dry season image chosen as a reference and the wet season image of interest (IOI) (Wagner et al., 2000; Zribi et al., 2006). The reference image is selected to be representative of the soil roughness when no vegetation is present (here the 20 December). In situ measurements show that surface soil roughness does not strongly vary between dry and wet seasons over sandy soils. The instrument used is a $2 \mathrm{~m}$ long needle like profilometer with a $1 \mathrm{~cm}$ horizontal sampling distance, allowing the estimation of standard deviation of roughness heights and the autocorrelation length. Measurements were made in August 2005 (wet season) and February 2006 (dry season) at the Agoufou site (Table 3) with a total of 60 and 16 profiles for the wet and dry seasons, respectively. Results show that the roughness parameters for sandy soils do not significantly vary between the two contrasted seasons. Since the surface of sandy soils are the most sensitive to meteorological conditions (wind, rain) and animal trampling, it is assumed constant roughness values over time for the other soil types as well.

4. A mask of the Niger River is built from the soil map and applied to the whole set of ASAR images. Masks are also applied over mixed surfaces for which the relation between SSM and $\sigma^{0}$ is unknown.

5. Finally, SSM maps are estimated at kilometric scale from the difference between the dry reference image and images acquired during the wet season over the meso-scale window by applying empirical inversion functions estimated for sandy and rocky soils. Coefficients of these linear functions are given in Table 4. Because of residual negative SSM values, a minimal threshold of $0.5 \%$ is imposed.
Table 4. Correlation coefficients $(r)$ between local surface soil moisture and normalized backscattering coefficient at the three considered local sites. Only descending orbit data $(D)$ are considered for the rocky Eguerit site.

\begin{tabular}{llll}
\hline Site & Agoufou & Ebang Mallam & Eguerit \\
\hline Soil type & Sandy & Sandy & Rocky \\
Correlation coefficient $r$ & 0.85 & 0.48 & 0.53 \\
Number of Samples & 42 & 44 & 20 \\
Regression Function & $\mathrm{a}=2.5$ & $\mathrm{a}=3.1$ & $\mathrm{a}=4.5$ \\
Hum $(\%)=a \cdot x(d B)+b$ & $\mathrm{~b}=36.7$ & $\mathrm{~b}=42.6$ & $\mathrm{~b}=66.5$ \\
\hline
\end{tabular}
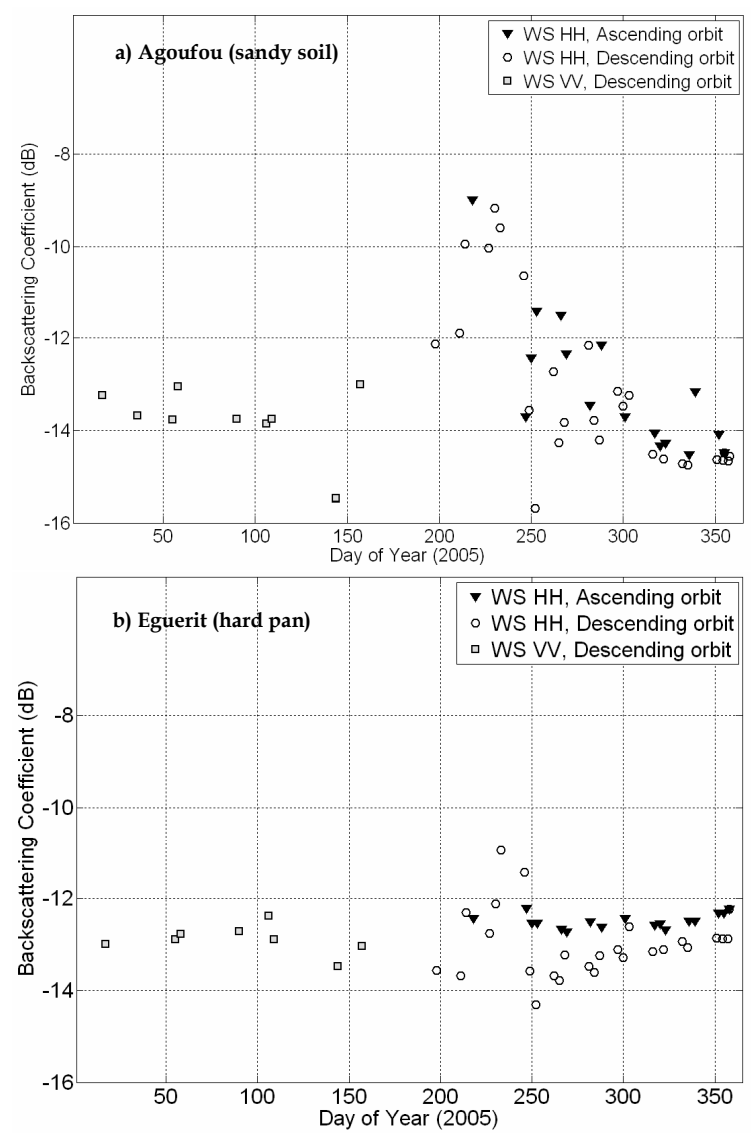

Fig. 6. Temporal variation of the normalized $\left(23^{\circ}\right)$ backscattering coefficient in 2005 for the Agoufou sandy (a) and the Eguerit rocky (b) sites.

\section{Surface soil moisture maps}

\subsection{Relationships between SSM and normalized $\sigma^{0}$}

Figure 6 presents the temporal variation of the normalized backscattering coefficient for the two main soil types at the sandy Agoufou (Fig. 6a) and hard pan (rocky) Eguerit (Fig. 6b) sites. 
As already indicated in Baup et al. $(2007 \mathrm{a}, \mathrm{b})$, the backscattering coefficient, $\sigma^{0}$, over the Agoufou sandy site displays a strong seasonal dynamics ( $>5 \mathrm{~dB}$ ), due both to the growth of annual herbs and to high SSM values reached during the wet season. In contrast, the seasonal dynamics of $\sigma^{0}$ recorded on the Eguerit rocky site is much weaker $(<2 \mathrm{~dB})$ due to both a low vegetation cover (Hiernaux et al., 2009) and overall low SSM.

Correlation coefficients between $\sigma^{0}$ and SSM for the three considered local sites are presented in Table 4 and associated regression functions are plotted in Fig. 7. The highest values are observed for the sandy site of Agoufou $(r \sim 0.85)$. The second sandy site, Ebang Mallam, exhibits a lower correlation coefficient $(r=0.48)$ due to a higher spatial heterogeneity in terms of vegetation cover and soils.

For the rocky site, Eguerit, backscattering coefficients are weakly correlated with SSM $(r=0.53)$, even for descending passes which show the highest $\sigma^{0}$ dynamics. This could be explained by two main reasons. The first one is associated to the difficulties of measuring soil moisture in such a medium composed of gravels and rocks for which the used SSM probes are not specifically designed. The second difficulty originates from the high spatial heterogeneity of soil texture within the site due to the presence of sparsely distributed sandy-loamy sheets. This justifies the exclusion of mixed soil types in the SSM mapping process. Finally, the total of soil and land cover types excluded from the analysis represent $28 \%$ of the meso-scale site; this also includes the Niger River and seasonally flooded acacia forests.

\subsection{SSM maps}

Following the methodology described in Sect. 2.4, SSM maps are generated at meso-scale. On the resulting images, black pixels result from either the applied mask or the lack of radar data (see for example Fig. 8). At meso-scale, the evaluation of SSM maps is a difficult exercise since no direct comparison is possible with SSM ground data. Here, the ASAR SSM maps are thus interpreted with the help of EPSAT-SG rainfall estimations, WSC soil moisture products and raingauges data. Because they differ in spatial resolution ( $1 \mathrm{~km}, 10 \mathrm{~km}$ and $25 \mathrm{~km}$, respectively), their spatial patterns are compared in a first analysis.

Figure 8 shows the generated SSM map corresponding to the beginning of the 2005 rainy season (16 July, DoY 197). Patches of high SSM to the North of Tin Tadeini can be related to the precipitations that fell during the 4 previous days totalling 10 to $12 \mathrm{~mm}$ (Fig. 8). Rainfall occurred on the same day (a total of $2 \mathrm{~mm}$ estimated from EPSAT-SG) have a minor influence since this quantity is very small for such an arid area. Raingauge records at Tin Tadeini $(6 \mathrm{~mm})$ confirm the occurrence of rainfall events. The large strip of high SSM to the South of Agoufou can be related to $25 \mathrm{~mm}$ cumulative estimated rainfalls (EPSAT-SG) over the 4 previous days confirmed by the raingauge records in Agoufou

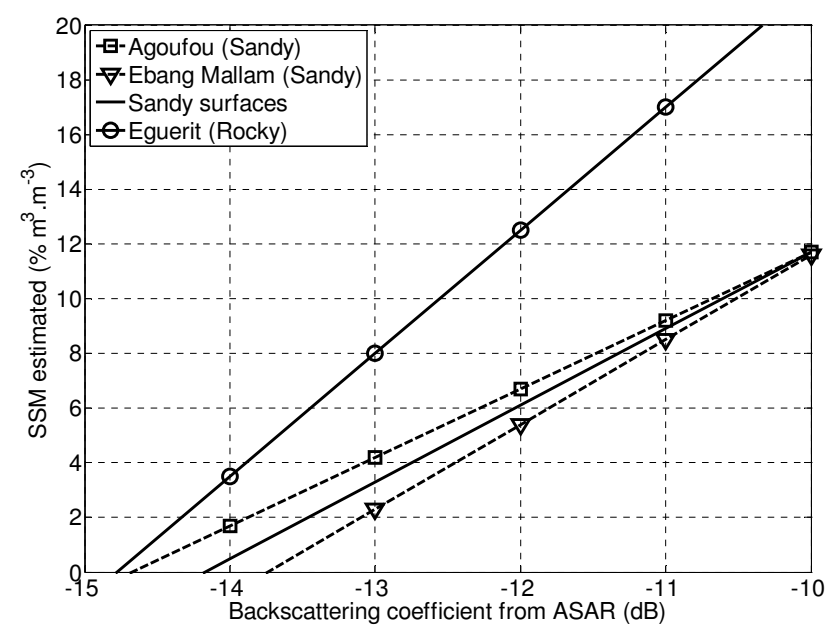

Fig. 7. Surface Soil Moisture - Backscattering coefficient regression functions estimated over the two sandy sites and the rocky site. The final regression function used over sandy surfaces is also plotted.

$(17 \mathrm{~mm})$. Overall, most of the SSM values are still below the noise threshold (a SSM of 4\%). This can be attributed both to speckle effects which are not completely removed at $1 \mathrm{~km}$ scale, and to local higher SSM values associated to topographic effects (depressions, small dunes) and to different soil textures. No WSC soil moisture product is available at this date over the whole meso-scale site.

During the wet season (Figs. 9 and 10), soil moisture maps of sandy soils display different patterns. On 4 August (DoY 216), general large scale spatial trend of the SSM map shows an overall good agreement with the daily rainfall EPSAT-SG map, especially in the Northern part of the considered window (Fig. 9). Particularly, the SSM maps point out the high spatial heterogeneity of SSM due to fine scale rainfalls events that are not observed in the ESPSAT-SG data. Besides, spots of high SSM values located in the South also indicate residual moisture due to past rainfall events supported by the cumulative EPSAT-SG product (about $35 \mathrm{~mm}$ of rain cumulated over the previous 4 days). This weak temporal signature of SSM confirms the limit of 4 days to detect the occurrence of rainfall events over sandy soils (Baup et al., 2007b). A high infiltration rate on sandy soils associated to high evaporation rates explain the rapid decrease of SSM at the soil surface. The finer spatial resolution of ASAR data provide information about the geographic distribution of rain events estimated by EPSAT-SG. Local SSM station data are in accordance with satellite products in the Southern part of the image, and with the recorded cumulative rainfall of about $39 \mathrm{~mm}$ at Agoufou.

WSC products show a strong agreement with ASAR products but with much higher SSM values estimated during the dry season as already observed by Gruhier et al. (2010). 


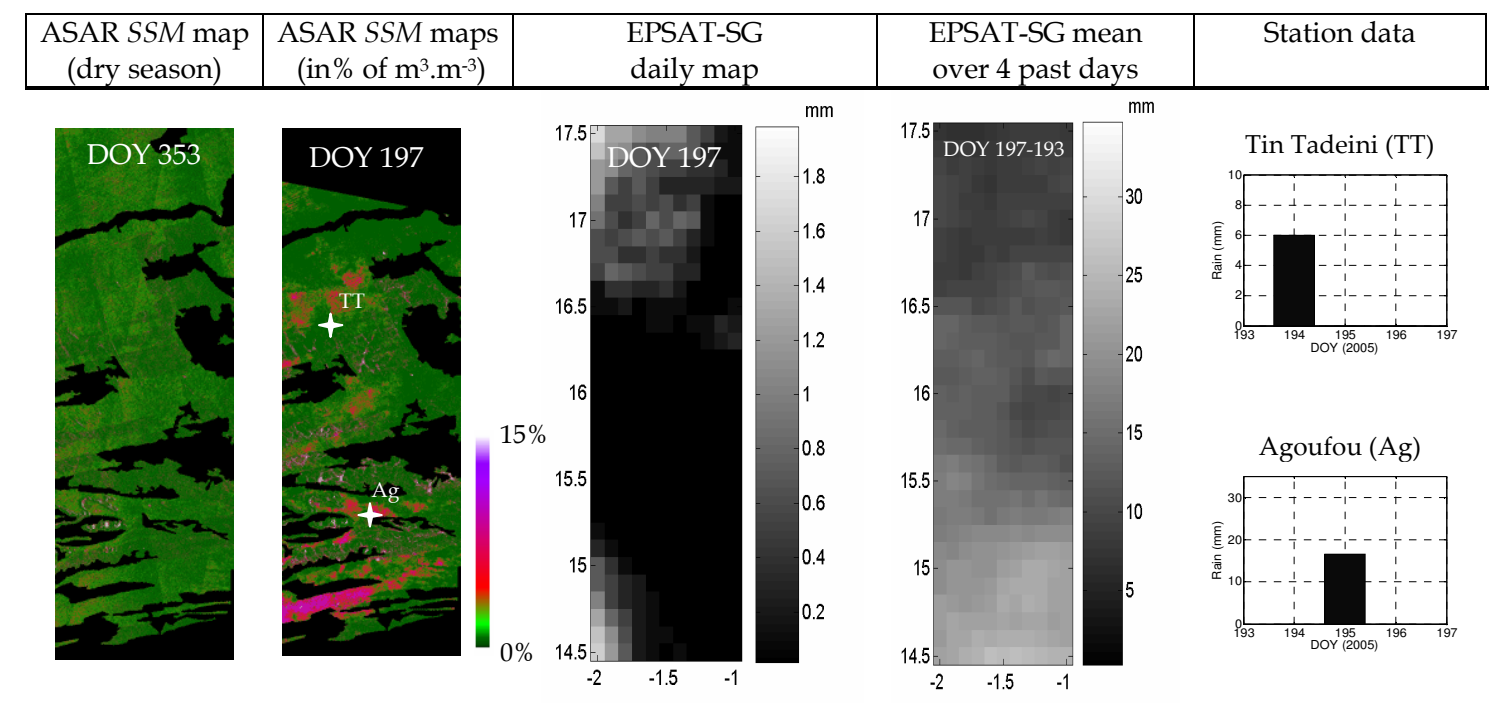

Fig. 8. Soil moisture (SSM) maps established during the 2005 dry (December, 19) and wet (July, 16) seasons compared to EPSAT-SG rainfalls estimates on the same day and over the four previous days and with rainfall recorded at Agoufou and Tin Tadeini during the five same days.
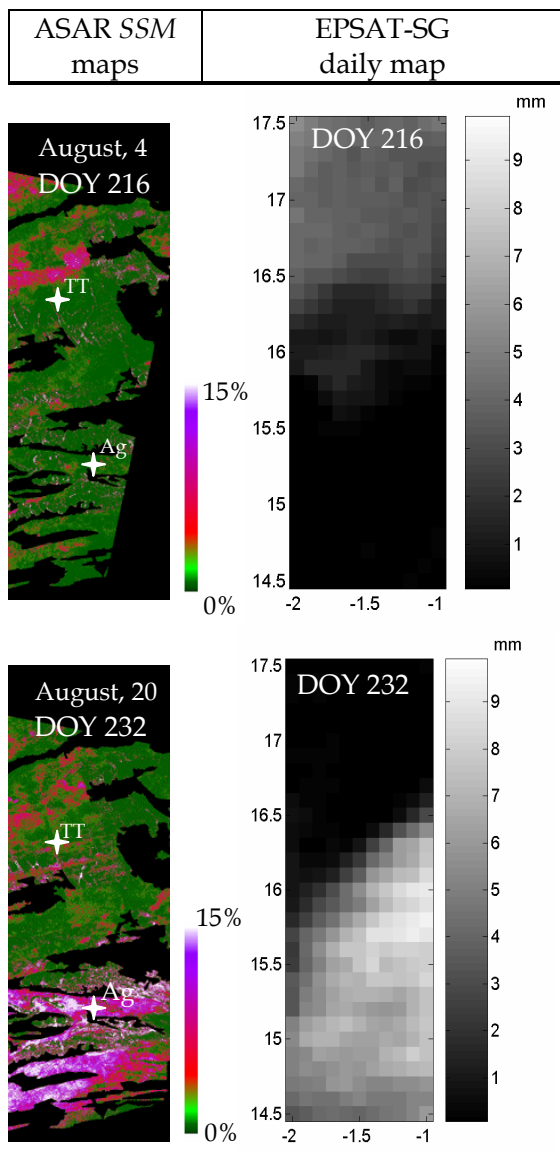
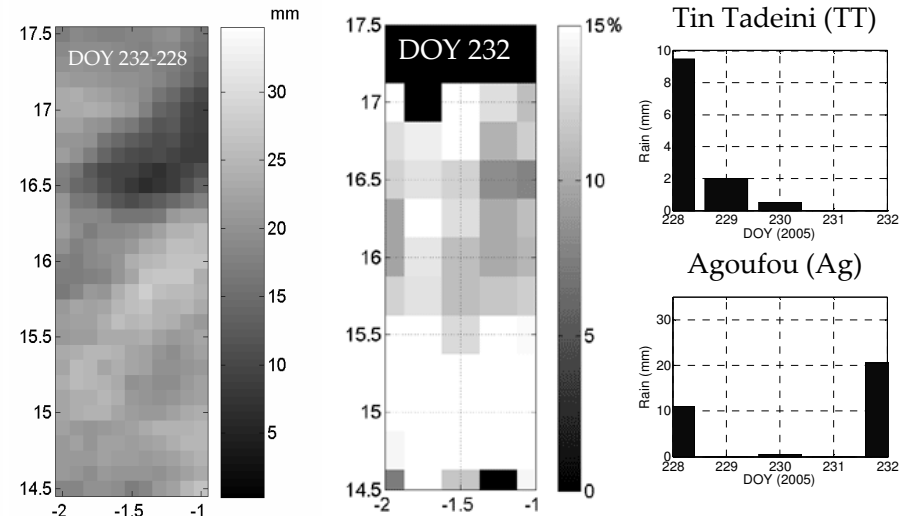

Fig. 9. Comparisons of August soil moisture (SSM) maps $\left(4^{\text {th }}\right.$ and $\left.20^{\text {th }}\right)$ derived from ENVISAT-ASAR and ERS WSC SSM products and EPSAT-SG rainfalls estimates on the same day and over the four previous days and with rainfall recorded at Agoufou and Tin Tadeini during the five same days. 

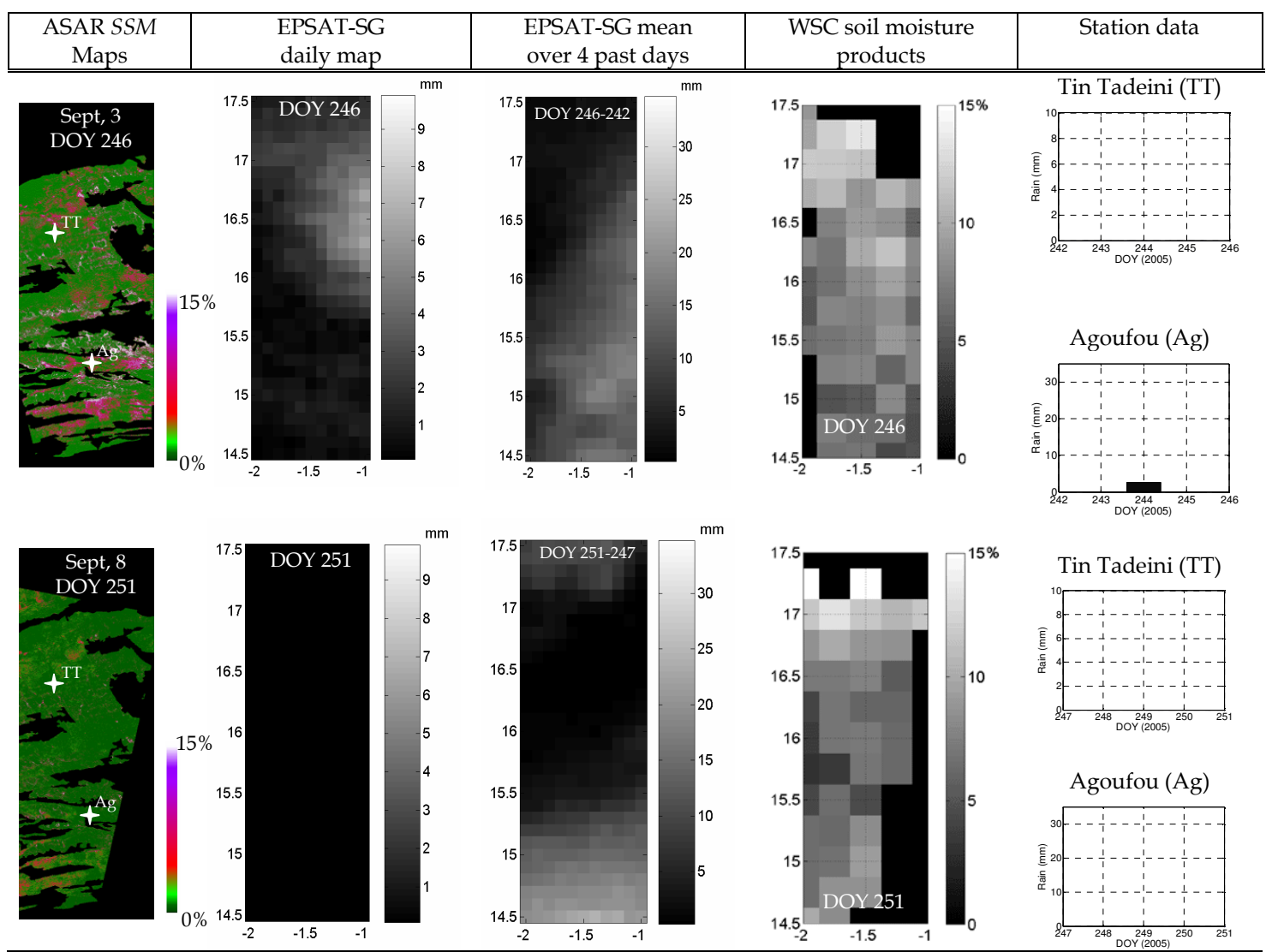

Fig. 10. Comparisons of September soil moisture (SSM) maps $\left(3^{\text {rd }}\right.$ and $\left.8^{\text {th }}\right)$ derived from ENVISAT-ASAR and ERS WSC soil moisture products and EPSAT-SG rainfalls estimates on the same day and over the four previous days, and with rainfall recorded at Agoufou and Tin Tadeini during the five same days.

On 20 August (DoY 232), the SSM map is highly contrasted with a large swath of saturated SSM values (20\%) in the Southern Gourma that corresponds to the occurrence of a large convective system a few hours before the radar image acquisition (EPSAT-SG product indicates $8 \mathrm{~mm}$ and Agoufou local station recorded $21 \mathrm{~mm}$ ). High and medium SSM values are more scattered in Northern Gourma in relation with rain events that occurred during the previous days (20 mm EPSAT-SG cumulated rains in the North, confirmed by $11 \mathrm{~mm}$ recorded at Tin Tadeini over 3 days). The WSC product exhibit high values in the South and in the NorthWest part of the meso-scale site (up to 20\%) in agreement with EPSAT-SG cumulative products.

On 3 September (DoY 246), the SSM map displays local patches that can be related to local rain events observed on EPSAT-SG rainfall products during the previous days (about $20 \mathrm{~mm}$ along a Northeast to Southwest stripe) (Fig. 10). The Agoufou raingauge station also recorded a rainfall event but of only $2.5 \mathrm{~mm}$ during on DoY 244 .

On 8 September (DoY 251), the accumulation of medium SSM values in the Southern part of the site can be related to the occurrence of a convective system during the 4 previous days. In accordance with EPSAT-SG maps, no rains are recorded at Tin Tadeini nor at Agoufou during the day corresponding to the ASAR acquisition. Local patches of high SSM values can also be observed in Northern and Central parts of the map. They are attributed to residual moisture in depressions as no rainfall has been monitored.

In contrast, soil moisture patterns derived from WSC data are not in accordance with ASAR and EPSAT products. Indeed, despite no rainfall occurred during the 4 previous days before the radar acquisition (WSC and ASAR), only low resolution products indicate high surface soil moisture in the Northern part of the image. This phenomenon is locally attributed to the presence of the Niger River and to flooded vegetation which highly contribute to increase the backscattering coefficient. High resolution data allow this specific region to be masked and prevent from overestimated SSM values.

Overall, the temporal variation of SSM values (0 to 10\%) that can be observed from $14.5^{\circ} \mathrm{N}$ to $17^{\circ} \mathrm{N}$ is small during the entire dry season (Gruhier et al., 2010). 


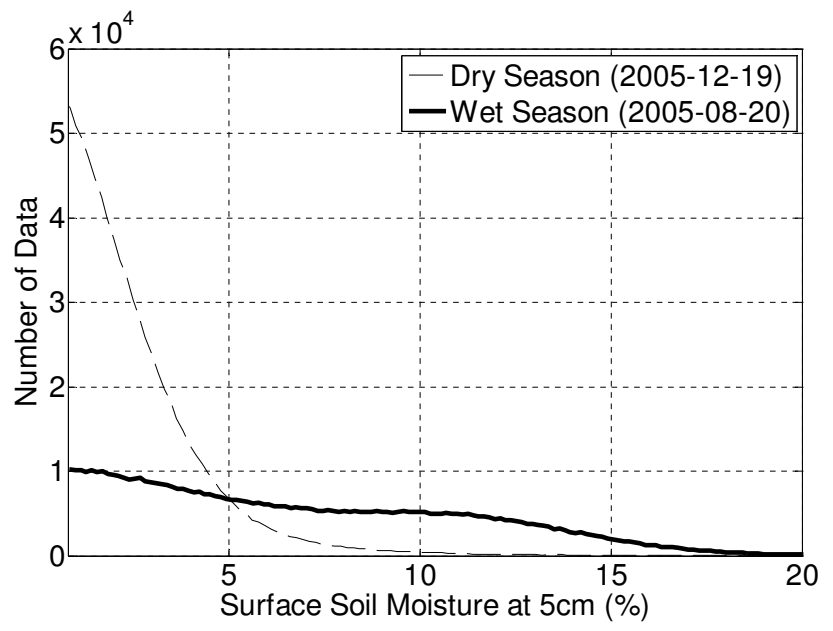

Fig. 11. Distribution of soil moisture (SSM) values $\left(\% \mathrm{~m}^{3} \mathrm{~m}^{-3}\right)$ at meso-scale site during the dry and the wet 2005 seasons.

\section{Evaluation of SSM ASAR maps}

At meso-scale, the distribution function of SSM values drastically changes between the dry and the wet seasons (Fig. 11). Mean (standard deviation) SSM values are about 1\% (1.8) and 4\% (5.0) for the dry and wet season, respectively. The 19 December (dry season) and the 20 August (wet season) maps exemplify it well (Figs. 8 and 9). During the wet season, higher values reach about $20 \%$ in accordance with local automatic measurements. The dry season distribution indicates that SSM values mainly range between 0 and $4 \%$ due to radar signal instability $( \pm 0.6 \mathrm{~dB})$ during this period (Baup et al., 2007a, b).

Among the different products used in this study, only the ERS WSC ones can be used for a quantitative evaluation of the ASAR SSM maps. Furthermore, both data sets are derived from radar sensors operating at the same frequency $(5.3 \mathrm{GHz})$. To enable a direct comparison, $1 \mathrm{~km}$ resolution ASAR maps are aggregated to the WSC spatial resolution $(25 \mathrm{~km})$. Then, the comparison is made by considering the ASAR pixels corresponding to at least $95 \%$ of a WSC pixel. Figure 12a and $\mathrm{b}$ shows the results obtained from SSM maps generated for the driest and wettest dates in 2005 (8 and 20 September, respectively). For each selected pixel, its latitudinal location is also indicated.

Dry and wet periods are separated in the analysis to better discriminate between noise effects and radiometric changes related to SSM. During the dry season characterised by no rainfall event, WSC-derived SSM of the order of 3\%-10\%, is obviously overestimated, as already mentioned by Gruhier et al. (2010) (Fig. 12a). The observed bias of 6\% between ASAR SSM and WSC SSM also confirms this overestimation. The highest SSM values are located in the Northern part of the site where the WSC signal is mainly affected by the Niger River and flooded vegetation. The initial offset of a)

Latitude

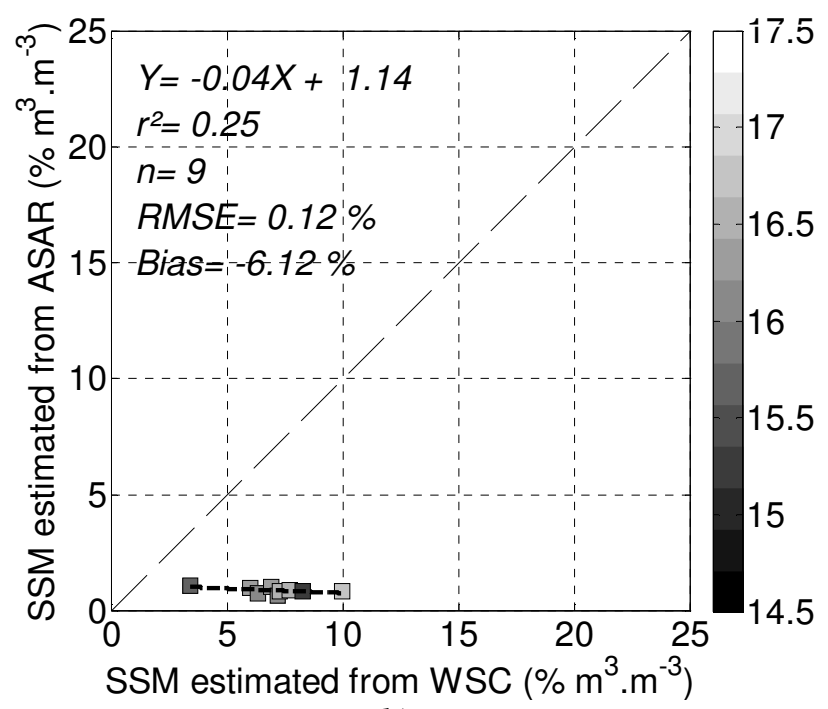

b)

Latitude

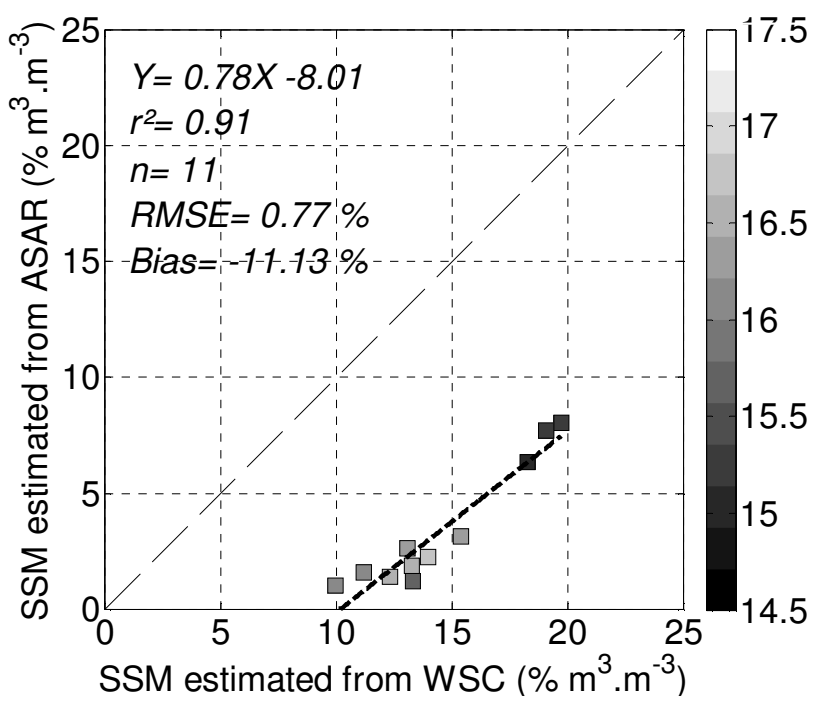

Fig. 12. Comparisons of SSM values estimated from ENVISAT ASAR and ERS-WSC data for the 2005 driest (a) and wettest (b) dates (8 September 2005 and 20 August 2005, respectively). The location of SSM pixels versus the latitude is also indicated.

$3 \%$ is explained by the inversion method initially developed over slightly wetter surfaces (see Zribi et al., 2008). In contrast, ASAR-derived SSM show a higher stability with only $2 \%$ of dynamic range and an offset of about $1 \%$.

Results obtained for the rainy season indicate a high correlation $\left(r^{2}=0.91\right)$ between the two datasets with a low rms error $(0.77 \%)$ despite the small number of considered samples $(n=11)$ which results from both the small number of available ASAR images and the small size of the Gourma site compared to the WSC product (at the resolution of $25 \mathrm{~km}$ ). 
The $11 \%$ bias observed during the wet season confirms the general overestimation trend of ERS/WSC SSM products.

\section{Concluding remarks}

A local empirical methodology inversion of SSM from ENVISAT/ASAR data has been generalized and applied at meso-scale at the AMMA site in Mali. Resulting soil moisture maps take into account surface roughness, vegetation density and angular variation of $\sigma^{0}$. They offer both a moderate spatial resolution $(1 \mathrm{~km})$ and a large spatial coverage $\left(30000 \mathrm{~km}^{2}\right)$ contrary to the maps derived from the Alternate Polarization (AP) high resolution (Zribi et al., 2007) and Global Monitoring (GM) low resolution modes (Wagner et al., 2005) that were previously used for that purpose.

During the 2005 wet season, five dates are available characterized by a large soil moisture dynamics. On the whole, there is a good agreement and consistency between ASAR derived SSM maps and EPSAT-SG rainfall fields and local rainfall measurements. Finally, when aggregated to 25 $\mathrm{km}$ resolution, the ASAR- derived SSM maps are found to be in a very good agreement with ERS WSC-derived SSM maps generated during the wet season. Furthermore, in contrast to ERS WSC dry season maps which show unrealistic high SSM values, ASAR derived maps exhibit low and constant SSM values during the whole dry season. These results demonstrate the great potential of ASAR WS images for mapping and monitoring SSM at moderate resolution $(1 \mathrm{~km})$ in semi-arid regions. Such SSM products could be advantageously used to desaggregate lower resolution images, such as those derived from AMSR, SMOS or ERS WSC data (Wagner et al., 2000; Berger et al., 2002; Njoku et al., 2003).

In the future, temporal SSM monitoring in the Sahel could be improved by combining ASAR Wide Swath data to other existing microwave sensors. Indeed, the ASAR WS temporal resolution of about 8 days is still insufficient to enable fast varying surface variables like soil moisture to be accurately monitored. For instance, the combination with ALOS/PALSAR (L-Band) data should improve the sampling of SSM temporal variations while keeping a good spatial resolution.

In the near future, with the launch of the Sentinel satellites, the temporal resolution of SAR images will significantly increase ( $<6$ days, depending on the latitude) and become more suitable for monitoring the high temporal dynamics of the SSM over arid or semi-arid areas.

Acknowledgements. This work was performed within the framework of the AMMA project. Based on a French initiative, AMMA has been constructed by an international group and is currently funded by large number of agencies, especially from France, the UK, the US and Africa. It has been the beneficiary of a major financial contribution from the European Community's Sixth Framework Research Programme. Detailed information on the scientific coordination and funding is available on the AMMA international web site (https://www.amma-eu.org/). The authors thank ESA for providing the ENVISAT data used in the present study (Project ID 443, E. Mougin). The authors are grateful for all the help they received during the field measurement campaigns, especially from their colleagues and collaborators from the national institute for agronomic research in Mali, the "Institut d'Economie Rurale".

Edited by: W. Wagner

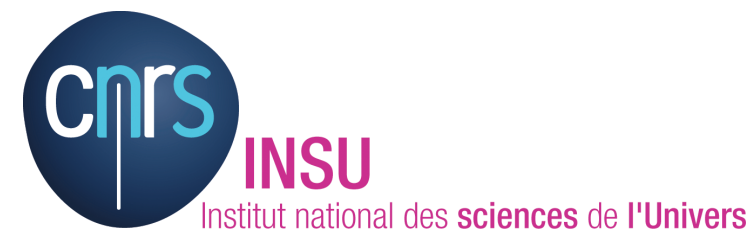

The publication of this article is financed by CNRS-INSU.

\section{References}

Baup, F., Mougin, E., D. Rosnay, P., Timouk, F., Lavenu, F., and Chênerie, I.: Surface soil moisture estimation over the AMMA sahelian site in Mali using ENVISAT/ASAR data, Remote Sens. Environ., 109, 473-481, 2007a.

Baup, F., Mougin, E., Hiernaux, P., Lopes, A., De Rosnay, P., and Chênerie, I.: Radar signatures of Sahelian surfaces in Mali using ENVISAT-ASAR data, IEEE T. Geosci. Remote., 45, 2354 2363, 2007b.

Berger, M., Camps, A., Font, J., Kerr, Y., Miller, J., Johannessen, J., Boutin, J., Drinkwater, M. R., Skou, N., Floury, N., Rast, M., Rebhan, H., and Attema, E.: Measuring Ocean Salinity with ESA's SMOS Mission, ESA Bulletin 111, 113f, 2002.

Bergès, J. C. and Chopin, F.: Satellite rainfall estimation using a feed forward network: improvement and limitation, Proc. of the International Conference on Cloud Climatology and Precipitation, Bologna, 2004.

Bergès, J. C., Chopin, F., and Bessat, F.: Satellite based downscaling for rainfall estimation, Proc. of the IV Coloquio Brasiliero de Ciencas Geodesicas, Curitiba, 2005.

Cappelaere, B., Descroix L., Lebel T., Boulain N., Ramier D., Laurent J.-P., Le Breton E., Boubkraoui S., Boucher M., Bouzou Moussa I., Chaffard V., Hiernaux P., Issoufou H. B. A., Le Breton, E., Mamadou I., Nazoumou Y., Oi, M., Ottlé, C., andv Quantin, G.: The AMMA-Catch experiment in the cultivated Sahelian area of south-west Niger - Investigating water cycle response to a fluctuating climate and changing environment, J. Hydrol., 375, 34-51, 2009.

Casenave, A. and Valentin, C.: Les états de surface de la zone sahélienne. Influence sur l'infiltration. ORSTOM, collection Didactiques, Paris, 229 p., 1989.

Chanzy, A., Schmugge, T. J., Calvet, J.-C., Kerr, Y., Oevelen, P. V., Grosjean, O., and Wang, J. R.: Airbone microwave radiometry on a semi arid area during HAPEX-Sahel, J. Hydrol., 188-189, 285-309, 1997. 
Chopin, F., Bergès, J. C., and Desbois M.: Using MSG for GPCP products enhancement, Proc. of the 1st International AMMA conference, oral presentation, Dakar, (available at http: //amma-international.org/), 2005.

Clark, D. B., Taylor, C. M., Thorpe, and A. J.: Feedback between the land surface and rainfall at convective length scales, J. Hydrometeorol., 5, 625-639, 2004.

de Rosnay, P., Gruhier, C., Timouk, F., Baup, F., Mougin, E., Hiernaux, P., Kergoat, L., and LeDantec, V.: Multi-scale soil moisture measurements at the Gourma meso-scale site in Mali, J. Hydrol., 375, 241-252, 2009.

Desnos, Y. L., Laur, H., Lim, P., Meisl, P., and Gach, T.: The ENVISAT-1 Advanced Synthetic aperture radar processor and data products, Geoscience and Remote Sensing Symposium, IGARSS'99, Hamburg, Germany, 1683-1685, 1999.

ENVI Programmer's Guide: Research System, Inc., 930 pp., 1998.

ENVISAT ASAR product Handbook: European Space Agency, Issue 2.2. 564 pages, available at: http://envisat.esa.int/ handbooks/, 2007.

Frappart, F., Hiernaux, P., Guichard, F., Mougin, E., Kergoat, L., Arjounin, M., Lavenu, F., Koité, M., Paturel, J. E., and Lebel, T.: Rainfall regime across the Sahel band in the Gurma region, Mali, J. Hydrol., 375(1-2), 128-142, doi:10.1016/j.jhydrol.2009.03.007, 2009.

Frison, P. L. and Mougin, E.: Use of the ERS-1 Wind scatterometer data over land surfaces. IEEE T. Geosci. Remote. 34(2), 550560, 1996.

Frison, P. L., Mougin, E., and Hiernaux, P.: Observations and interpretation of Seasonal ERS-1 Wind Scatteromter Data over Northern Sahel (Mali), Remote Sens. Environ., 63, 233-242, 1998.

GEWEX-news: Global Energy and Water Cycle Experiment, special issue "AMMA west African monsoon studies are addressing water cycle issues", 16(1), 20 pp., 2006.

Gruhier, C., de Rosnay, P., Hasenauer, S., Holmes, T., de Jeu, R., Kerr, Y., Mougin, E., Njoku, E., Timouk, F., Wagner, W., and Zribi, M.: Soil moisture active and passive microwave products: intercomparison and evaluation over a Sahelian site, Hydrol. Earth Syst. Sci., 14, 141-156, doi:10.5194/hess-14-1412010, 2010.

Hiernaux, P., Mougin, E., Diarra, L., Soumaguel, N., Lavenu, F., Tracol, Y., Diawara, M., and Jarlan, L.: Rangeland response to rainfall and grazing pressure over two decades: herbaceous growth pattern, production and species composition in the Gourma, Mali, J. Hydrol., 375, 114-127, 2009.

Jackson, T. J., Bindlish, R., Gasiewski, A. J., Stankov, B., Klein, M., Njoku, E. G., Bosch, D., Coleman, T. L., Laymon, C. A., and Starks, P.: Polarimetric scanning radiometer $\mathrm{C}$ - and X-band microwave observations during SMEX03, IEEE T. Geosci. Remote, 43(11), 2418-2430, 2005.

Jarlan, L., Mougin, E., Frison, P. L., Mazzega, P., and Hiernaux, P.: Analysis of ERS wind scatterometter time series over Sahel (Mali), Remote Sens. Environ., 81, 404-415, 2002.

Laur, H., Bally, P., Meadows, P., Sanchez, J., Schaettler, B., Lopinto, E., and Esteban, D.: Derivation of the backscattering coefficient so in ESA SAR products. ESA publication, Document No: ES-TN-RS-PM-HL09 17, Issue 2, Rev. 5d., 53 pp., 1998.

Lebel T., Cappelaere B., Galle S., Hanan N., Kergoat L., Levis S., Vieux B., Descroix L., Gosset M., Mougin E., Peugeot C., and Seguis L.: AMMA-CATCH studies in the Sahelian region of
West-Africa: an overview, J. Hydrol., 375, 3-13, 2009.

Mattia, F., Satalino, G., Dente, L., and Pasquariello, G.: Using a priori information to improve Soil Moisture Retrieval from ENVISAT ASAR AP data in semiarid regions, IEEE T. Geoscie. Remote, 44, 900-912, 2006.

Mladenova, I., Lakshmi, V., Walker, J. P., Panciera, R., Wagner, W., and Doubkova, M.: Validation of the ASAR Global Monitoring Mode Soil Moisture Product Using the NAFE' O5 Data Set, IEEE T. Geosci. Remote, 48, 2498-2508, 2010.

Monteny, B. A., Lhomme, J. P., Chehbouni, A., Troufleau, D., Amadou, M., Sicot, M., Verhoef, A., Galle, S., Said, F., and Lloyd, C. R.: The role of the Sahelian biosphere on the water and the $\mathrm{CO}_{2}$ cycle during the HAPEX-Sahel Experiment, J. Hydrol., 188-189, 516-535, 1997.

Moran, M. S., Hymer, D. C., Qi, J., and Sano, E. E.: Soil moisture evaluation using-temporal synthetic aperture radar (SAR) in semiarid rangeland, Agri. Forest Meteorol., 105, 69-80, 2000.

Mougin, E., Lopes, A., Frison, P. L., and Proisy, C.: Preliminary analysis of the ERS-1 wind-scatterometer data over land surfaces, Int. J. Remote Sens., 16(2), 391-398, 1995.

Mougin E., Hiernaux P., Kergoat L., Grippa M., de Rosnay P., Timouk, F., Le Dantec, V., Demarez, V., Lavenu, F., Arjounin, M., Lebel, T., Soumaguel, N., Ceschia, E., Mougenot, B., Baup, F., Frappart, F., Frison, P.L., Gardelle, J., Gruhier, C., Jarlan, L., Mangiarotti, S., Sanou, B., Tracol, Y., Guichard, F., Trichon, V., Diarra, L., Soumaré, A., Koité, M., Dembélé, F., Lloyd, C., Hanan, N.P., Damesin, C., Delon, C., Serça, D., Galy-Lacaux, C., Seghieri, J., Becerra, S., Dia, H., Gangneron, F., and Mazzega, P.: The AMMA Gourma observatory site in Mali: Relating climatic variations to changes in vegetation, surface hydrology, fluxes and natural resources, J. Hydrol., 375, 14-33, 2009a.

Mougin, E., Demarez, V., Grippa, M., Hiernaux, P., Larouzière, L., Lion, C., Diawara, M., and Soumaguel, N.: Evaluation of MODIS LAI products in a sahelian environment (Gourma, Mali), Poster presented at the $4 \mathrm{~h}$ Global vegetation workshop, University of Montana, Missoula, June 16-19, 2009 b.

Njoku, E. G., Jackson, T. J., Lakshmi, V., Chan, T. K., and Nghiem, S. V.: Soil Moisture Retrieval From AMSR-E, IEEE T. Geoscie. Remote, 41(2), 215-229, 2003.

Panciera, R., Walker, J. P., Kalma, J. D., Kim, E. J., Hacker, J. M., Merlin, O., Berger, M., and Skou, N.: The NAFE'05/CoSMOS data set: Toward SMOS Soil moisture retrieval, Downscaling, and Assimilation. IEEE T. Geosci. Remote, 46, 736-745, 2008.

Pathe, C., Wagner, W., Sabel, D., Doubkova, M., and Basara, J. B.: Using ENVISAT ASAR Global Mode for surface soil moisture retrieval over Oklahoma, USA, IEEE T. Geosci. Remote, 47, 468-480, 2009.

Schmugge, T., Jackson, T., Kustas, T. J., and Wang, J. R.: Passive microwave remote sensing of soil moisture: results from HAPEX, FIFE and MONSOON'90, ISPRS J. Photogramm., 47, 127-143, 1992.

Tansey, K. J., Millington, A. C., Battikhi, A. M., and White, K. H.: Monitoring soil moisture dynamics using satellite imaging radar in northeastern Jordan. Appl. Geogr., 19, 325-344, 1999.

Taylor, C. M. and Ellis, R. J.: Satellite detection of soil moisture impacts on convection at the mesoscale, Geophys. Res. Lett., 33(3), L03404, doi:10.1029/2005GL025252, 2006. 
Timouk, F., Kergoat, L., Mougin, E., Lloyd, C. R., Ceschia, E., Cohard, J.-M. , de Rosnay, P., Hiernaux, P., Demarez, V., and Taylor, C. M.: Response of surface energy balance to water regime and vegetation development in a Sahelian landscape, J. Hydrol., 375(1-2), 178-189, doi:10.1016/j.jhydrol.2009.04.022, 2009.

Ulaby, F. T., Fung, A. K., and Moore, R. K.: Microwave and remote sensing active and passive. Norwood, MA: Artech House, 1981.

Ulaby, F. T., Fung, A. K., and Moore, R. K.: Microwave and remote sensing: active and passive: surface scattering and emission theory, Norwood, MA: Artech House, 1982.

Wagner, W. and Scipal, K.: Large-scale Soil moisture mapping in western Africa using the ERS Scatterometer, IEEE T. Geosci. Remote, 38, 1777-1782, 2000.

Wagner, W., Scipal, K., Bartsch, A., and Pathe, C.: ENVISAT's Capabilities for Global Monitoring of the Hydrosphere, Geoscience and Remote Sensing Symposium 2005 (IGARSS '05), IEEE International, 8, 5678-5680, 2005.
Wagner, W., Pathe, C., Doubkova, M., Sabel, D., Bartsch, A., Hasenauer, S., Blöschl, G., Scipal, K., Martinez-Fernandez, J., and Löw, A.: Temporal stability of soil moisture and radar backscatter observed by the advanced synthetic aperture radar (ASAR), Sensors, 8, 1174-1197, 2008.

Zine, S., Jarlan, L., Frison, P. L., Hiernaux, P., and Rudant, J. P.: Land surface parameter monitoring with ERS scatterometer data over the Sahel: A comparison between agro-pastoral and pastoral areas, Remote Sens. Environ., 96, 438-452, 2005.

Zribi, M., Andre, C., Saux-Picard, S., Descroix, L., Otlle, C., and Kallel, A.: Soil moisture mapping based on ASAR/ENVISAT radar data over a sahelian region. Int. J. Remote, 29, 3547-3565, 2007.

Zribi, M., André, C., and Decharme, B.: A method for soil moisture estimation in Western Africa based on ERS Scatterometer, IEEE T. Geosci. Remote, 46(2), 438-448, 2008. 